\title{
Federal Reserve Banks as Fiscal Agents and Depositories of the United States in a Changing Financial Environment
}

Donna A. DeCorleto and Theresa A. Trimble, of the Board's Division of Reserve Bank Operations and Payment Systems, prepared this article.

The Federal Reserve Act assigns to the Federal Reserve Banks the task of serving as fiscal agents and depositories of the United States when required to do so by the Secretary of the U.S. Department of the Treasury. Generally, the appointment as fiscal agent has been taken to confer authority to act for, or in place of, the federal government in matters relating to public revenues, public debt, and other financial business. The term depository has retained its usual meaning as a place where something is deposited, especially for safekeeping. Within these broad definitions, the role of the Reserve Banks as fiscal agents and depositories has evolved substantially since the relevant provisions of the Federal Reserve Act were implemented in $1915 .^{1}$

An article in the April 2000 Federal Reserve Bulletin described the Reserve Banks' fiscal agent services at that time as being mainly the issuance and redemption of securities on behalf of the Treasury, federal agencies, and specific other entities, along with the processing of payments to and from the federal government. ${ }^{2}$ That article also described the way that most of those services, which from the beginning of the Federal Reserve System had been paper- and labor-intensive, had evolved to highly automated operations. This shift paralleled changes that had occurred throughout the financial services industry over the past few decades as paper processing yielded to automated processing.

Although the basic fiscal agent services have not changed since the article was published in 2000, considerable changes have occurred in the way those services are provided — changes that, again, have par-

Note. Paula V. Hillery, Stephen E. Thompson, and Kimberly A. Snell provided assistance in preparing this article.

1. Unless otherwise indicated, any reference to a specific year in this article refers to the calendar year.

2. See Paula V. Hillery and Stephen E. Thompson, "The Federal Reserve Banks as Fiscal Agents and Depositories of the United States," Federal Reserve Bulletin, vol. 86 (April 2000), pp. 251-59. alleled important developments within the financial services industry. The increasing use of the Internet and related electronic technologies are prime examples. The Treasury and the Reserve Banks have implemented new web-based technology to improve the federal government's provision of services in the areas of securities, payments, and collections as well as government-wide financial reporting, much the same as financial services firms have used web-based technology to improve the ways that they do business and communicate with their customers. The challenge, as with the financial services industry generally, is to manage complex and rapidly evolving information technologies, while maintaining high standards of security, efficiency, and reliability.

After reviewing the evolution of the Reserve Banks' fiscal agent role since the early days of the twentieth century, this article highlights the fiscal agent and depository services that the Reserve Banks provide today and their recent changes.

\section{HISTORICAL PERSPECTIVE}

The provision of fiscal agent and depository services officially commenced in 1915 when the Treasury designated three Reserve Banks (Banks) as depositories for Treasury funds. ${ }^{3}$ In this capacity, the Banks maintained the Treasury's bank account and served as intermediaries through which the Treasury collected and disbursed funds for the federal government. In January 1916 the nine remaining Banks became depositories and all twelve assumed the role of fiscal agents. Over time, the Banks' roles as fiscal agents and depositories have become closely intertwined. For the purposes of this article, therefore, the term fiscal agent is used to refer to both services. The Board of Governors oversees these Bank activities but is neither a fiscal agent nor a depository.

In their initial role, the Banks, as fiscal agents of the United States, accepted taxes and customs duties,

3. The Reserve Banks are not the exclusive depositories of the Treasury (see 31 U.S.C. 3303). 
held deposits for the Treasury, cleared Treasury checks and warrants, and redeemed Treasury coupons. In 1917, when the United States became involved in World War I, the Treasury directed the Banks to place issues of short-term Treasury certificates and redeem them at maturity, thereby adding securities activities to the fiscal agent role. Subsequently, the Banks handled issues of the government's Liberty Loan bonds and Victory notes, receiving subscriptions and payments for the securities from, and delivering them to, investors within their Districts.

These bonds and notes were sold throughout the country, and the Treasury needed an efficient way to transfer the proceeds of the securities sales from the location of the sale to the government contractors that produced war materiel. To accommodate this need, the Banks exchanged messages by telegraph to transfer large amounts of money across the country. Because some proceeds from securities sales were held at depository institutions, the Banks also began to safekeep collateral that was pledged to the Treasury to protect those funds. The Banks' success in handling these tasks influenced the Treasury in 1921 to end its network of subtreasuries-field offices that functioned as the government's bank in various regions of the country-and to transfer to the Banks many of the operational functions related to financing the public debt.

The advent of World War II, and with it the need for a massive amount of financing to wage that war, resulted in further expansion of the Banks' fiscal agent role. The new duties included issuing, servicing, and redeeming War Savings Bonds, which the Treasury introduced in 1941. The handling of these bonds became one of the largest single operations that the Banks performed. By the second half of 1942, approximately 4,000 Bank employees, or 20 percent of the workforce, were involved in savings bond operations. ${ }^{4}$ Between 1940 and 1944, the annual volume of securities transactions soared from 3.8 million to 357.8 million items, primarily because of War Savings Bond sales. After the war ended, the Treasury retained the bond program, dropping the word "war" from the title. Savings bond issuance declined after the 1940s, but savings bonds remained popular with the public.

In the 1960s and 1970s, the Banks' role as fiscal agents expanded again, this time to provide services-primarily securities-related services-to other federal government agencies, government-

4. See the Annual Report of the Board of Governors of the Federal Reserve System, 1942, pp. 31-32. sponsored enterprises, and international organizations, either at the Treasury's request or through a separate congressional mandate. ${ }^{5}$ However, the primary recipient of Bank fiscal agent services continued to be the Treasury, particularly as the volume of Treasury securities transactions grew dramatically, both within local markets and between counterparties in different geographic regions. The Federal Reserve and the Treasury explored ways to reduce the amount of time and paperwork associated with these transactions, and in January 1968 the Banks introduced book-entry securities safekeeping and transfer. ${ }^{6}$ These services reduced the time required to process and deliver government securities and facilitated the nationwide expansion of the secondary market for government securities.

In addition to securities transactions, payments made by paper check grew rapidly in the post-World War II era, which helped prompt the development of the automated clearinghouse (ACH) network in the 1970s. This nationwide network enabled depository institutions to automate the exchange of payments using magnetic tapes, punch cards, and printed advices instead of paper checks and thereby expedited the processing of both government and commercial payments. The federal government was an early user of ACH services through the Banks, first in late 1973 for the U.S. Air Force payroll and the following year to make some Social Security payments. The government's use of the ACH became permanent in 1975, and the ACH now plays a central role in the government's payments and collections (see box "Use of the Automated Clearinghouse System" for further discussion of the ACH process as it exists today).

From the 1970s until the late 1990s, the nature of fiscal agent services did not change dramatically: the Banks continued to issue and redeem securities, process both paper-based and electronic payments, monitor collateral for Treasury funds, and maintain the government's bank account. The most significant development during the period was the steady transition from paper-based, labor-intensive operations performed at a large number of Bank offices to highly automated operations performed at a few offices. ${ }^{7}$ For example, in the 1990s, savings bond processing was

5. See the appendix for information about government agencies, government-sponsored enterprises, and international organizations authorized through specific legislation to receive Bank services.

6. A book-entry security is a security represented by an accounting entry, or an electronic record, and not by a paper certificate.

7. The number of Bank offices exceeds the number of Banks because most Banks operate additional offices that are either Branches or specialized processing sites. 


\section{Use of the Automated Clearinghouse System (ACH)}

The automated clearinghouse $(\mathrm{ACH})$ system is an electronic payment system developed jointly by the private sector and the Federal Reserve in the early 1970s as an electronic alternative to paper checks. Since then, the $\mathrm{ACH}$ has evolved into a nationwide mechanism that processes credit and debit transfers electronically. $\mathrm{ACH}$ credit transfers are used to make direct deposits of payroll payments as well as corporate payments to contractors. ACH debit transfers are used by consumers to authorize the payment of mortgages, loans, and other bills from their accounts. More recently, the ACH has been used to make one-time electronic payments over the telephone and the Internet. The ACH is also used by businesses to concentrate funds at a primary bank and to make payments to other businesses.

The Federal Reserve Banks operate FedACH, the Banks' central clearing facility for transmitting and receiving ACH payments. The federal government uses FedACH extensively. For example, the Treasury uses FedACH to make approximately 81 percent of all Social Security benefit payments and 98 percent of all Treasurydisbursed federal salary payments. ${ }^{1}$ Social Security benefits can serve as an example of how such payments are processed. For the millions of Social Security recipients who receive their payments electronically, the Social Security Administration (SSA) creates an electronic $\mathrm{ACH}$ file instead of printing and mailing checks. The file specifies payment amounts and depository institution routing information for payments due on a certain date. On behalf of the SSA, the Treasury sends the file electronically to the Banks three or four days before the payment date. The Banks check certain data for accuracy, sort the information by receiving depository institution, send a payment file to each receiving depository institution, and initiate accounting entries to debit the Treasury's account and credit each receiving depository institution's account at the Banks. The receiving depository institution credits each customer's account on the scheduled payment date.

1. This percentage does not include certain salary payments that the Treasury does not disburse, such as military payrolls.

consolidated from twenty-seven locations to five. Similarly, as the Treasury moved many government payment and collection transactions from paper checks to electronic payments, the number of Bank offices that processed Treasury checks declined, from more than forty offices to fewer than ten.

Since the end of the 1990s, the Banks have continued to improve existing fiscal agent services. For example, they have reduced to three the number of offices that process Treasury checks and are in the process of combining savings bond and retail marketable securities operations into a single function operated in just two locations. In addition, fiscal agent activities have evolved beyond simply automating paper-based operations. They now include using new technology to support specific Treasury Department needs, such as using the Internet to initiate payments to and from the government, providing stored-value cards to the military, and enhancing governmentwide financial reporting-services discussed later in this article (see the sections "Electronic Government Payment Services" and "Information Services"). 8 These new types of services support the Treasury's efforts to provide better, more convenient services to government agencies and the general public.

As new services have been provided, the Banks have had to develop and operate new software applications and computer systems and to manage specialized information technology vendors on the Treasury's behalf. The Banks have also applied new technology and skills to improve existing fiscal agent services. As other innovative uses of technology develop and the Treasury continues to enhance its operations and services, the Banks' fiscal agent activities undoubtedly will evolve further. Regardless of the specific activities or the technology employed, a fundamental part of the fiscal agent role continues to be maintaining the security and integrity of the Banks' and the Treasury's information and systems.

The Banks' current fiscal agent activities-their roles in issuing and redeeming securities, processing payments to and from the federal government, and keeping account of all of these activities - are discussed in the remainder of this article. Highlighted are the ways in which fiscal agent services have evolved with technology, either to make an existing business process more efficient or to use technology to develop innovative business processes and practices.

\section{SECURITIES-RELATED SERVICES}

The federal government issues debt to cover the shortfall between its expected receipts and expenditures and to refinance its maturing debt. Most of this debt is composed of securities issued by the Treasury; securities issued by other federal agencies account for any remaining debt. The Banks play an integral role in the Treasury's financing operations.

8. A stored-value card is a (plastic) payment card that has prepaid value assigned to it. 


\section{Treasury Marketable Securities}

The Treasury sells new marketable securities to investors through periodic auctions. ${ }^{9}$ Typically, the securities are auctioned in a regular pattern; however, the pattern may be changed to accommodate the government's borrowing needs. The terms and conditions of sale for securities being auctioned are announced by the Treasury on or before the auction day, and investors are invited to submit bids. The Banks developed and operate a computer application that compares all bids submitted in an auction, assists the Treasury in determining the lowest acceptable price offered, and then calculates the amount to be awarded to each bidder. ${ }^{10}$

Because of the increased automation that the Banks have applied to the auction process, the Treasury can now announce its auction results to the public electronically, usually within two minutes of the auction closing. By shortening the time between the close of the auction and the release of results, the Treasury and the Banks have decreased the risk to bidders of changes in market conditions that can occur between the close of bidding and the announcement of results.

On the security's issue date, the Banks issue bookentry securities for the Treasury via the Fedwire Securities Service (see box "The Fedwire Securities Service" for a discussion of its operations). The securities are delivered electronically to each successful bidder's designated Fedwire Securities Service account and the purchase price is simultaneously withdrawn from the bidder's funds account. ${ }^{11}$ Proceeds from the sales are deposited into the Treasury's account at the Banks. In 2003 the Banks supported 202 auctions, processing bids totaling almost $\$ 8.2$ trillion. ${ }^{12}$ When periodic interest payments are due and when securities mature or are called by the Treasury, the Fedwire Securities Service initiates those payments.

The Banks also use the Fedwire Securities Service to transfer securities ownership from one party to

9. The term Treasury marketable securities refers to Treasury bills, notes, bonds, and inflation-protected securities. These securities are readily bought and sold in the highly liquid secondary market.

10. Currently, the Treasury conducts single-price auctions in which all bidders that did not specify a price and all bidders that specified a price greater than or equal to the lowest acceptable price receive the securities at the lowest acceptable price. For details on Treasury auctions, see the Code of Federal Regulations, chapter 31, part 356.

11. Bidders that do not have a Fedwire Securities Service account must designate a depository institution that has an account to receive the securities and make payment on their behalf.

12. The Banks also help the Treasury redeem, or buy back, Treasury securities when that action fits within the Treasury's debt management strategy. In buyback operations, the Treasury purchases Treasury securities from the current owners through a competitive bidding process and then retires the debt.

\section{The Fedwire Securities Service}

The Fedwire Securities Service is a system for safekeeping and transferring certain book-entry securities. It consists of an electronic vault that stores records of book-entry securities holdings, by account holder, and a transfer-and settlement-mechanism used by depository institutions to transfer custody of book-entry securities from one depository institution to another. The securities stored on the Fedwire Securities Service include U.S. Treasury bills, notes, bonds, and inflation-protected securities; U.S. agency securities; mortgage-backed securities issued by Freddie Mac, Fannie Mae, and Ginnie Mae; and securities of certain international organizations such as the World Bank.

As part of the Fedwire Securities Service, the Banks maintain multiple book-entry accounts for each depository institution; reconcile activity in each account; issue transaction advices and account statements; credit interest and principal to the accounts; and move securities between accounts at the request of the account holder. By allowing participants convenient yet secure access to their book-entry securities holdings, the Fedwire Securities Service contributes to the efficiency and liquidity of the secondary market in these securities.

The Fedwire Securities Service held in safekeeping \$28.5 trillion in Treasury, government agency, government-sponsored enterprise, and international organization securities as of September 30, 2004. (For information on the rules governing Treasury book-entry securities, see 31 CFR Parts 356 and 357.)

another when parties trade securities in the secondary market. The Fedwire Securities Service enables the seller to deliver the securities to the purchaser's Fedwire Securities Service book-entry account and to simultaneously receive the agreed-upon payment in a funds account. In 2003 the Fedwire Securities Service handled 9.4 million transfers of Treasury securities, a total value of $\$ 202.6$ trillion.

As fiscal agents, the Banks also operate another automated book-entry securities system known as TreasuryDirect. TreasuryDirect is designed for retail customers-nonfinancial organizations and individuals who generally keep their Treasury securities from initial issue to maturity and who prefer to hold their securities directly with the Treasury instead of with a depository institution or securities broker. The Banks issue confirmation notices and account statements to the TreasuryDirect account holders and credit interest and principal payments to their accounts with their depository institutions. TreasuryDirect investors can purchase Treasury securities, check their account balances, request statements, and perform other routine account functions using the Internet or a touch-tone 
telephone. As of September 2004, TreasuryDirect maintained almost 705,000 accounts, holding a total of $\$ 61.8$ billion of Treasury securities.

When TreasuryDirect account holders wish to sell securities, they can direct the Banks to transfer the securities to a broker for sale or can request that the Banks sell the securities for them on the secondary market. The Treasury charges sellers a fee for this service. In 2003 the Banks sold $\$ 671.6$ million of securities for TreasuryDirect account holders.

Another securities service provided to the Treasury and government agencies by the Banks is monitoring securities pledged to the government by depository institutions as collateral for government deposits, or by businesses or individuals as security in lieu of a surety bond. The Banks monitor the collateral's value and prevent it from being released unless other acceptable collateral has been substituted or the government determines that the collateral is no longer required.

\section{Savings Bonds}

Individual investors help fund government programs when they purchase savings bonds, which are government securities that can be purchased with an initial investment of as little as \$25. In contrast to other Treasury securities, there is no secondary market for savings bonds, and they cannot be transferred easily between investors, though they can be redeemed before maturity. Current offerings comprise series EE and series I bonds, both of which accrue interest until final maturity. ${ }^{13}$ As of September 2004, \$204 billion of savings bonds, representing approximately 4.7 percent of the federal public debt, was outstanding.

The Banks issue, service, and redeem savings bonds for the Treasury. Over the past several years, they have issued between 40 million and 41 million savings bonds and serviced or redeemed between 4 million and 5 million each year. Investors can purchase savings bonds in person from many depository institutions, by mail from a Bank or the Treasury, or on the TreasuryDirect website, www.TreasuryDirect.gov. In October 2002 the Treasury introduced the "paperless" version of series I savings bonds, making it possible for investors to purchase and hold these bonds in book-entry form directly with the Treasury. In May 2003 the Treasury introduced book-entry EE bonds to the public and announced a goal to transform the savings bond

13. Effective September 1, 2004, the Treasury discontinued the issuance of series $\mathrm{HH}$ bonds, which pay interest semiannually. program from one based on paper certificates to one based on book-entry accounts that can be accessed safely and conveniently on the Internet at www.TreasuryDirect.gov. ${ }^{14}$ Because of these innovations and recent automation enhancements at the Banks, by year-end 2005 the number of Banks processing savings bond transactions will decline from five to two.

\section{PAYMENT SERVICES}

The evolution of the Banks' payments-related fiscal agent services has paralleled their involvement in the broader U.S. payments system. The Banks process electronic payments for depository institutions through the ACH or the Fedwire Funds Service. They also continue to clear large volumes of checks. Providing these services gives the Banks a strong foundation for delivering similar high-quality services to the Treasury and for assisting the Treasury with improvements and innovations in its services.

In their role as fiscal agents, the Banks process several types of payments for the federal government, including salary and benefit payments, interest and principal payments, and vendor payments. Although some of these payments are still made by check, the Treasury has been committed for several years to shifting government payments from paper checks to electronic payments. In fiscal year 2003, 74 percent of Treasury-disbursed payments, by value (\$1.4 trillion), were made electronically using the ACH or the Fedwire Funds Service, compared with 68 percent in fiscal year 1999. ${ }^{15}$ Several factors have contributed to this increase, including the public's greater acceptance of electronic payments. In addition, the Debt Collection Improvement Act of 1996 mandated that federal agencies, starting in 1999, make their payments electronically unless the agencies or their payment recipients receive a waiver from the Secretary of the Treasury. The Banks have supported the Treasury's efforts to explore the reasons some individuals prefer receiving paper checks rather than electronic payments and then to help address those issues or concerns. The Banks continue to work closely with the Treasury to automate the remaining paper-based government payments by using new technologies or using existing technologies in innovative ways.

14. See Bureau of the Public Debt press release, "Electronic EE Savings Bonds Added to TreasuryDirect," dated May 5, 2003.

15. The federal government's fiscal year begins on October 1 and ends on September 30 of the following calendar year. 


\section{Electronic Government Payment Services}

The Banks operate two payment services used by the federal government to make electronic payments, FedACH and the Fedwire Funds Service. They also participate in the automation of other payment services.

\section{FedACH}

FedACH is the Banks' electronic service used for payments that do not need to be originated and settled on the same day. Today, ACH payments are made by transferring payment files electronically instead of using magnetic tape or punch cards, as in the past. The Treasury uses FedACH to make recurring payments, such as payroll and Social Security benefits, and for some one-time payments, such as federal tax refunds. The number of government $\mathrm{ACH}$ payments first exceeded the number of government check payments in 1991, and since then ACH payments have continued to increase relative to check payments. In 2003 the Banks processed 914 million ACH payments for the government, compared with 267 million check payments.

\section{Fedwire Funds Service}

The Fedwire Funds Service is an electronic funds transfer system that provides immediate settlement of payments. It is generally used for large-dollar payments and for payments that must be settled on the same day that they are originated. In 2003 the Banks processed 667,000 outgoing Fedwire funds transfers for the Treasury.

\section{Other Electronic Payment-Related Initiatives}

In addition to processing payments for the Treasury, the Banks have participated in several initiatives to develop specialized applications that help federal agencies use electronic methods to improve their overall payments processes.

Grant payments. One payment-related initiative is the Treasury's Internet-based Automated Standard Application for Payments (ASAP.gov). The Banks developed and operate this computer application, which enables individuals and organizations that receive federal grant payments to submit payment requests electronically using the Internet and to receive payment electronically. For example, state treasurers and their contractors use ASAP.gov to request reimbursement for Medicare and Medicaid expenses and to specify payment by FedACH or the Fedwire Funds Service. The ASAP.gov application sends each request for payment to a related computer application (called ASAP), which is operated by a Bank, that reviews the request, compares it with the parameters established by the granting agency, and-if the transaction is in order-initiates the payment. In 2003 ASAP initiated $\$ 384.2$ billion in payments.

Food stamp payments. The Banks also developed and operate a related computer application that enables the U.S. Department of Agriculture's Food and Nutrition Service to electronically distribute funds for its food stamp program. This application is used to verify and reconcile depository institutions' deposits of food stamps, and then ASAP is used to initiate the payments to the depository institutions.

Intra-governmental payments. Government agencies regularly pay each other for goods and services. In the past, many of these payments were made by check. At the Treasury's request, the Banks developed a computer application that electronically transfers information and funds between government agencies, thereby reducing or eliminating the need for paper invoices and agency-to-agency checks. About 300 government agencies currently use this service.

Vendor payments. Government agencies regularly use the services of commercial vendors. After identifying several aspects of this activity that might benefit from Internet-based technology-exchanging purchase orders and invoices, making payments, and researching discrepancies-the Treasury initiated a pilot program, the Internet Payment Platform, to gain further information and in 2003 directed the Banks to manage the program. Three federal agencies and their vendors used a central website to exchange electronic purchase orders and invoices and to initiate $\mathrm{ACH}$ payments. Approximately $\$ 20$ million in payments were processed before the pilot was concluded in June 2004. After evaluating the pilot, the Treasury has decided to proceed with a permanent program and has asked the Banks for further support in this area.

Military personnel payments. Another paymentsrelated area for which the Treasury has sought the Banks' assistance has been the provision of stored- 
value cards for the Defense Department. The department faces several challenges in making payments to military personnel. One is the ongoing need to provide cash or its equivalent to personnel on military bases and on ships at sea. Another is making payments at basic training camps, where recruits need cash immediately to purchase necessities but in many cases do not have bank accounts. To address these challenges, the Treasury initiated several prepaid payment card programs for the Defense Department. One program provides military personnel at certain locations with reloadable cards that can be used to make purchases from merchants located on the military bases and in some cases to transfer funds between service personnel. Two other programs use nonreloadable cards to provide pay advances to recruits in basic training. Approximately 108,000 cards were outstanding under these programs at midyear 2004. The Banks' roles in these programs are to maintain detailed transaction and accounting records for the Treasury, to maintain card balances, to pay participating merchants via the $\mathrm{ACH}$, and to develop and maintain related computer applications. ${ }^{16}$

International benefit payments. Making payments, such as Social Security and pension payments, to recipients living abroad is another payments-related operation for which the Treasury has sought Bank assistance. Receiving U.S. government checks can have drawbacks for those living abroad, including long mail-delivery times and fees for depositing or cashing checks denominated in U.S. dollars outside the United States. Some non-U.S. banks were willing to accept electronic payments, such as Social Security payments, from the Treasury, but only if the payments were made in their local currencies. The Treasury and the Banks developed a process to convert benefit payments into the currency of the country in which the beneficiary does his or her banking and then to send the payment electronically as a direct deposit. In 2003, \$893 million was sent to individuals in thirty-nine countries using this process.

In 2004 the Banks began sending government $\mathrm{ACH}$ payments to one country using FedACH International. This is the same mechanism the Banks have been developing to send and receive commercial $\mathrm{ACH}$ payments across borders. ${ }^{17}$

16. A U.S. depository institution operates a separate payment card program for service personnel on ships at sea. Those cards can also be used as debit cards when the individuals are on shore.

17. FedACH International is the Banks' service that accelerates the clearing time and reduces the costs associated with making crossborder payments using the ACH system.
Paper-Based Government Payment Services

\section{Paper Checks}

While the use of electronic payments continues to expand throughout the federal government, some payments remain paper-based, and the Banks play an important role in processing these payments. When a depository institution presents a Treasury check to a Bank for payment, the Bank credits the depository institution, makes an image of the check, and forwards the paper check to a federal records center for storage. ${ }^{18}$ In 2003 the Banks processed 266.9 million Treasury checks, a 7.4 percent decline from the volume in 1999, consistent with the government's strategy of moving away from paper and to electronic payments.

As the environment in which paper-check payments are made continues to change, so too do the services that the Banks provide to the Treasury as fiscal agents. For instance, the Check Clearing for the 21st Century Act, which took effect on October 28, 2004 , will affect the way paper checks are processed. ${ }^{19}$ The Banks are working closely with the Treasury to implement processes to take full advantage of the Check 21 Act's provisions.

\section{Postal Money Orders}

In addition to Treasury checks, the Banks also process postal money orders for the U.S. Postal Service. Postal money orders are prepaid drafts drawn against the Postal Service's account with the Treasury. Individuals purchase these money orders with cash and use them as they do checks. When money orders are deposited for collection, the Banks pay, sort, and make images of these items and debit the Postal Service's account. Similar to the decline in the volume of Treasury checks, postal money order volume has also been declining: The Banks processed 198.3 million postal money orders in 2003, compared with 225.8 million in 1999 .

18. Check imaging is a process by which a high-quality, digital picture or image is taken of both sides of a check.

19. The Check 21 Act, as it is commonly known, authorizes a new negotiable instrument called a substitute check-a paper reproduction of an original check-and provides that a substitute check, properly prepared, is the legal equivalent of an original check. The act facilitates electronic check exchange by enabling depository institutions to sort and deliver checks electronically and, when necessary, to create legally equivalent substitute checks for presentment to depository institutions that have not agreed to accept checks electronically. This process enables depository institutions to reduce their handling and physical transportation of paper checks, which can be costly. 


\section{Fiscal Agent Checks}

Another specialized service that the Banks provide to the government is issuing and processing fiscal agent checks-checks issued by and drawn on the Bank in its capacity as fiscal agent of the United States in payment for a Treasury obligation, such as a redeemed savings bond. To the extent possible, the Banks make these payments electronically, but if the Treasury does not have information about a recipient's bank account, the Bank issues a fiscal agent check. Because the Banks initiate the payments, it is more efficient for them rather than the Treasury to issue the checks. The funds, however, ultimately are paid from the Treasury's account. Relatively few fiscal agent checks are issued, and the volume has been declining. In 2003 only 311,000 were issued, compared with 609,000 in 1999.

\section{Food Coupons}

The Banks perform one other paper-based fiscal agent service-processing paper food coupons issued under the food stamp program, which is operated by the U.S. Department of Agriculture's Food and Nutri tion Service. Although all benefits under the program have, since June 2004, been issued electronically rather than by paper, some coupons are still outstanding. Any merchant that redeems the coupons must deposit them with its depository institution, which forwards them to the Banks. The Banks verify the deposits, pass credit to the depositing institution, and destroy the paper coupons. They processed 286.6 million paper food coupons in 2003, compared with 1.2 billion in 1999. The Banks will continue to process the coupons until all have been redeemed or until the Banks are directed otherwise by the Food and Nutrition Service.

\section{COLLECTION SERVICES}

The federal government collects money through several programs, the largest of which is the program for collecting federal business taxes. Government agencies also collect funds for providing goods (such as government publications) and services (such as national park admission fees). The following sections describe the ways in which the Banks support various government funds collection programs.

\section{Federal Tax Collections}

Annually, the Treasury receives approximately $\$ 1.7$ trillion in income tax payments and payroll withholdings through three different mechanisms. The Banks are involved in all three operations.

\section{EFTPS}

About \$1.6 trillion of tax collections are received through the Electronic Federal Tax Payment System (EFTPS), a system for submitting tax payments via the ACH operated by depository institutions designated by the Treasury. ${ }^{20}$ The designated institutions send taxpayer information to the Internal Revenue Service (IRS) and forward ACH payment instructions to the Banks for processing. On the tax due date, the Banks debit the taxpayers' depository institutions' accounts and credit the Treasury's account. ${ }^{21}$

\section{FR-ETA}

To use the ACH feature of EFTPS, taxpayers must know their tax liability at least one day before the tax is due. However, some taxpayers, such as companies with variable payrolls and companies that are payroll processors, cannot calculate their payroll tax liability until the actual due date. For these taxpayers, the Banks, in the 1990s, developed the Federal ReserveElectronic Tax Application (FR-ETA) as an adjunct to EFTPS. The application enables taxpayers to pay their taxes on the due date by using the Fedwire Funds Service to transfer their payments to the Treasury's account at the Banks. In 2003 taxpayers used FR-ETA to submit approximately $\$ 276$ billion in tax payments, which is included in the $\$ 1.6$ trillion figure for EFTPS above.

\section{Paper Check}

Business taxpayers that still pay their taxes by check may submit a check payment with a tax coupon to

20. Business taxpayers that submit annual tax payments of $\$ 200,000$ or more are required to use EFTPS beginning the second calendar year following the year in which their tax payment first exceeds $\$ 200,000$, and in all succeeding years. Individuals making tax payments with forms 1040, 706 (estate taxes), or 709 (gift taxes) or making installment payments may also use EFTPS.

21. Tax payments submitted directly to the IRS using an online tax calculation and payment software package are also processed through the ACH mechanism. 
their depository institution or mail it directly to an IRS lockbox operated by a depository institution. Individuals who pay by check generally mail their payments and forms to an IRS lockbox. In either case, the depository institution forwards the tax coupon or form to the IRS and forwards the proceeds from the check to a Bank for deposit to the Treasury's account. Approximately 5 percent of total business and individual tax dollars in 2003 (or about $\$ 76$ billion) were paid by check.

\section{Investment of Collected Taxes}

In addition to assisting with the collection of taxes, the Banks, through the Treasury Tax and Loan (TT\&L) program, have been instrumental in helping the Treasury earn interest on tax proceeds (and other funds) that are not immediately needed. Throughout the day, the Banks deposit excess Treasury funds with prequalified depository institutions, ensure that the funds remain properly collateralized, and withdraw funds at the Treasury's request. While the funds remain on deposit, the Treasury earns interest at a rate of 25 basis points below the effective federal funds rate. Through this program, the Banks not only provide the Treasury with a safe and efficient way to manage its funds, but also help to implement monetary policy by keeping the balance in the Treasury's account with the Banks at a fairly stable level (see box "Relationship between the Treasury's Balance with the Reserve Banks and the Implementation of Monetary Policy"). In 2003 the Banks invested $\$ 1.8$ trillion of government funds through the TT\&L program.

The TT\&L program has changed over time as the Treasury and the Banks have added features and flexibility. A recent innovation has been the Term Investment Option, or TIO. Unlike regular TT\&L investments, which can be called at any time and earn a fixed interest rate, investments through the TIO offer government funds for a specified term, at an interest rate set at auction. These auctions, which are conducted by the Banks periodically, as instructed by the Treasury, have generally earned the Treasury a higher rate of return than regular TT\&L investments because the certainty of the term makes the funds more attractive to depository institutions. The Banks began the TIO as a pilot program in 2002, and in 2003 the Treasury made the program permanent. From October 2003 to October 2004, 42 TIO auctions were conducted through which almost $\$ 300$ billion of government funds were invested.

\section{Relationship between the Treasury's Balance with the Reserve Banks and the Implementation of Monetary Policy}

The Treasury maintains its primary account for making and receiving payments, the Treasury general account (TGA), at the Reserve Banks. An increase in the balance of that account means that funds have moved from depository institutions' accounts at the Banks into the TGA. This movement of funds reduces the amount of reserves in the banking system. ${ }^{1}$ Conversely, a decrease in the TGA means that funds have moved from that account to depository institutions, thereby increasing the amount of reserves in the banking system.

This relationship between the Treasury's balance with the Banks and the amount of reserves in the banking system is important from a monetary policy perspective. This is because the amount of reserves in the banking system affects the federal funds rate-the rate at which depository institutions lend reserves to other depository institutions and the operating objective of the Federal Open Market Committee (FOMC) in its conduct of monetary policy. Through open market operations-the purchase and sale of U.S. Treasury and federal agency securities on the open market-the FOMC adjusts the amount of reserves in the banking system so as to achieve the targeted federal funds rate. By fluctuating, the Treasury's balance at the Banks affects the level of reserves and, therefore, the conduct of monetary policy.

The Banks and the Federal Reserve Board work closely with the Treasury every day to ensure that the Treasury's balance with the Banks remains stable, between $\$ 5$ billion and $\$ 7$ billion. The Banks use the Treasury Tax and Loan program to shift amounts in excess of the targeted Treasury balance into depository institutions' accounts and, as a result therefore, back into the banking system.

1. Reserves are the funds that depository institutions hold as vault cash plus balances on deposit with Banks. Required reserves are the funds that depository institutions are required to hold either as vault cash or on deposit with a Bank. Depository institutions with reserves often lend such reserves, to institutions in need of reserves, through the federal funds market. Federal funds transactions are short-term loans between depository and certain other institutions.

\section{Other Collection Programs}

The Banks are involved to varying degrees in several other federal government collection programs.

\section{Pay.gov}

As fiscal agents, the Banks support the Treasury's efforts to improve other government collection pro- 
cesses. One such effort is Pay.gov—an Internet portal that federal agencies may make available to members of the public to do such things as submit information via forms and to authorize electronic payments to agencies. The Banks operate the computer application for this initiative and manage the vendors that perform technical support. They also enter Pay.gov payment instructions into FedACH and make related accounting entries for the Treasury. Pay.gov collected $\$ 3.7$ billion in 2003 on behalf of twenty-three agencies. Although agencies are not required to use Pay.gov, current agency users have found it to be an efficient means of collecting funds. The Treasury expects that more agencies will begin to use the portal as the Treasury adds features to Pay.gov and agencies become more familiar with it.

\section{Electronic Check-Processing Application}

In instances in which the Treasury has been unable to move government collections from paper checks to electronic methods, the Treasury and the Banks have worked together to improve the processes by which these checks are collected. An example of these efforts is Electronic Check Processing, an application operated by the Banks that permits a federal agency receiving a check in payment for goods or services to convert the check into an $\mathrm{ACH}$ payment, thereby expediting the availability of the funds to the agency. In addition to operating the computer application and entering the payment instructions, the Banks maintain a database containing digital images of the converted checks that agencies can view at a secure Internet site. In 2003 the Electronic CheckProcessing application converted more than 713,000 checks, totaling \$377.9 million.

\section{Treasury Offset Program}

Under the Debt Collection Improvement Act of 1996, the Treasury is responsible for collecting delinquent debts owed to the government. At the Treasury's direction, the Banks developed an application that compares the names associated with certain outgoing federal government payments with those on a list of delinquent debts owed to the government (federal or state), such as delinquent student loan or child support payments. The Treasury, which operates the application, intercepts the outgoing payments so that some or all of the funds can be applied to the amounts owed. For example, an individual who is due a tax refund but is delinquent on student loan payments will be identified and the delinquent amount will be deducted from the tax refund. In the case of delinquent child support payments, the funds recovered are sent to the custodial parent, or, if the custodial parent is receiving state assistance, to the state. In 2003 this application identified and offset $\$ 2.9$ billion in delinquent debt and child support payments.

\section{INFORMATION SERVICES}

The Banks are working with the Treasury to develop computer applications that will help improve governmentwide accounting, including the ability to access information concerning government financial transactions sooner and more efficiently. One such application will enable federal agencies to create electronic deposit tickets for use when depositing funds at any depository institution that accepts government deposits; agencies will then be able to track their deposits over the Internet as they are processed. A second application will categorize financial information for the Treasury and agencies at a more detailed level for use in their accounting applications. A third application will serve as a standardized data repository for detailed information about transactions from all government financial collection systems and depository institutions, giving the Treasury and federal agencies a more complete and readily accessible view of their cash positions and a better tool for meeting their financial management and reporting responsibilities.

\section{REIMBURSEMENT FOR THE RESERVE BANKS}

In 1917 the Secretary of the Treasury initiated the practice of reimbursing the Banks for their processing costs for fiscal agency services on behalf of the government. Until relatively recently, however, the Treasury was unable to obtain congressional funding sufficient to reimburse the Banks fully for services rendered. In November 1990, the Congress enacted legislation to provide money for this purpose beginning in fiscal year 1992, which covered public-debtrelated operating expenses incurred on behalf of the Treasury. ${ }^{22}$ A similar law was enacted in 1997 to permit the Treasury's Financial Management Service and other federal agencies to reimburse the Banks for expenses incurred on their behalf beginning with fiscal year 1998. ${ }^{23}$

22. Pursuant to Pub. L. 101-509, 104 Stat. 1394.

23. See 12 U.S.C. 391a. Other domestic and international organizations with direct legislative authority to use the Banks as fiscal agents also reimburse the Banks. 


\section{Additional Information on Fiscal Agent Services}

\author{
Websites \\ Department of the Treasury-Information on services \\ provided by the Department of the Treasury \\ www.treas.gov
}

Financial Management Service-Government payment and collection services and financial reports

www.fms.treas.gov

Bureau of the Public Debt-How Treasury finances the public debt

www.publicdebt.treas.gov

TreasuryDirect-Treasury securities, including savings bonds, and how to buy them

www.treasurydirect.gov

Department of Agriculture, Food and Nutrition ServiceFood Stamp Program

www.fns.usda.gov/fsp

\section{Printed Publications}

Board of Governors of the Federal Reserve System, Annual Report of the Federal Reserve System, 1914 through 1918, 1940, 1942, and 1944. Annual reports describing the inception and later expansion of Reserve Bank fiscal agent services.

Board of Governors of the Federal Reserve System, The Federal Reserve System: Purposes and Functions, 1994 (revised edition forthcoming). Further explanation of the services provided by the Reserve Banks to the Treasury and depository institutions.

C.H. Associates, A History of the Bureau of the Public Debt, 1940-1990, with historical highlights from 17891939, Danbury, CT; January 1990. Additional history on the instruments of the public debt.

Akhtar, M.A., Understanding Open Market Operations, Public Information Department, Federal Reserve Bank of New York (1997). Detailed explanation of the daily open market operations of the Federal Reserve System.

The full reimbursement of expenses incurred by Banks as fiscal agents and depositories is an important public policy concept that is strongly supported by the Banks and the Treasury for two reasons. First, if individual federal agencies do not include in their budget submissions to the Congress the costs incurred by Banks on their behalf, the Congress may have difficulty determining the cost to taxpayers for the agencies' operations. Second, when services are provided at no cost or are subsidized, they may be overused or there may be inadequate incentives to monitor the services and ensure that they are provided in an efficient manner. In calendar year 2003, the Treasury and the other fiscal principals reimbursed the Banks $\$ 327$ million for services performed as fiscal agents.

\section{CONCLUSION}

Fiscal agent services have changed considerably since the Treasury first designated the Banks as depositories and fiscal agents in 1915 and 1916. As the financial services industry has grown, the needs of the government have also changed. In recent years, technological developments, many involving the use of web-based technologies, have opened new opportunities for the Banks and the Treasury to work together to improve government services to the public, much as financial services firms have used new technologies to improve services to their customers.

Technological change is an ongoing phenomenon and the Banks' fiscal agent services undoubtedly will continue to evolve with change. Each new technology challenges the Banks to adjust their knowledge, activities, and organization to take advantage of this technology to meet the needs of the Treasury for efficient and effective fiscal agent and depository services. The Banks continue to explore with the Treasury innovative means of improving its services to the public in line with changing technology and public needs. See box "Additional Information on Fiscal Agent Services," for a list of other resources.

\section{APPENDIX}

\section{U.S. Law Enabling Federal Reserve Banks to Provide Services to the Federal Government}

The legal authorization for the Federal Reserve Banks to act as depositories and fiscal agents of the United States government, at the direction of the Secretary of the Treasury, is governed by section 15 of the Federal Reserve Act, as amended (codified at section 391 of title 12 of the United States Code). 
U.S. Laws Enabling Federal Reserve Banks to Provide Services Directly to Other Organizations

The legal authorization for the Federal Reserve Banks to provide depository, custodial, and fiscal agent services for certain government agencies, governmentsponsored enterprises, and international organizations directly can be found in certain statutory provisions codified in titles 12, 15, 20, 22, 41, and 42 of the United States Code, as follows:

Title 12 of the U.S. Code (Banks and Banking)

- Section 393-Farm Credit System institutions

- Section 395-Commodity Credit Corporation

- Section 1435-Federal Home Loan Banks

- Section 1441(h)(2)-Financing Corporation

- Section 1441b(h)(2)—Resolution Funding Corporation

- Section 1452(d)—Federal Home Loan Mortgage Corporation (Freddie Mac)

- Section 1795g-Central Liquidity Facility

- Section 1723a(g) - Federal National Mortgage Association (Fannie Mae) and Government National Mortgage Association (Ginnie Mae)

- Section 2279aa-3(d)—Federal Agricultural Mortgage Corporation (Farmer Mac)

Title 15 of the U.S. Code (Commerce and Trade)

- Section 635(a)—Small Business Administration

- Section 687(b)—Small Business Investment Companies

- Section 1849-Emergency Loan Guaranty Board

Title 20 of the U.S. Code (Education)

- Section 1087-2(1)—Student Loan Marketing Association (Sallie Mae)
Title 22 of the U.S. Code (Foreign Relations and Intercourse)

- Section 282d-International Finance Corporation

- Section 283d-Inter-American Development Bank

- Section 283ee-Inter-American Investment Corporation

- Section 284d-International Development Association

- Section 285d-Asian Development Bank

- Section 286d-International Monetary Fund/ International Bank for Reconstruction and Development (World Bank)

- Section 290g-5-African Development Fund

- Section 290i-5-African Development Bank

- Section 290k-7-Multilateral Investment Guarantee Agency

- Section 290m(f) - North American Development Bank

- Section 290o-3-Bank for Economic Cooperation and Development in the Middle East and North Africa

- Section 2901-3-European Bank for Reconstruction and Development

Title 41 of the U.S. Code (Public Contracts)

- Section 110(2)-Termination of War Contracts

Title 42 of the U.S. Code (Public Health and Welfare)

- Section $1437 \mathrm{~h}(\mathrm{c})$ - Housing and Urban Development 